\section{A DISTRIBUTED MODEL OF HYDROLOGICAL AND SEDIMENT TRANSPORT IN THE UPNM CATCHMENT}

\author{
Zuliziana Suifa*, Nordila Ahmada, Maidiana Othmana, Jestin Jelania \\ Chihiro Yoshimurab \\ aDepartment of Civil Engineering, Faculty of Engineering, Universiti \\ Pertahanan Nasional Malaysia, Kem Perdana Sg. Besi, 57000 Kuala \\ Lumpur, Malaysia \\ bDepartment of Civil Engineering, Tokyo Institute of Technology, 2- \\ 12-1-M1-4 Ookayama, Meguro-ku, Tokyo 152-8552, Japan
}

Article history

Received

16 August 2021

Received in revised form

13 January 2022

Accepted

13 January 2022

Published Online

21 December 2021

*Corresponding author zuliziana@upnm.edu.my

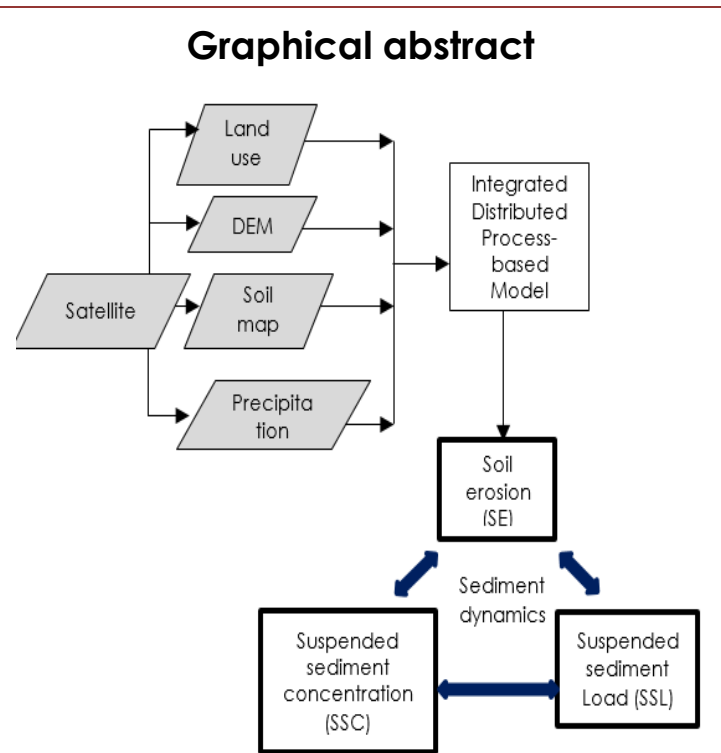

\begin{abstract}
Sediment transport models in river basins have been developed over the years for various temporal and spatial scales. However, yet few models have been reported for small-scale catchment and still under investigation by many researchers. In this paper, a distributed model based on process was presented for evaluating transportation of sediment in a small catchment scale. The integration of distributed hydrological and sediment model was developed for simulate the soil erosion and sedimentation processes in the catchment area located at Universiti Pertahanan Nasional Malaysia (UPNM). The finding prevailed that the simulation of suspended sediment load over a period of four years gave a good significant result with an average Nash-Sutcliffe Efficiency (NSE) and a Correlation Coefficient ( $r$ ) were of 0.60 and 0.78 , respectively. Moreover, sensitivity analysis revealed that the suspended sediment load in the UPNM catchment was influenced by soil detachability over land $\left(K_{f}\right)$. Overall, the outputs from the present model can be taken as input to predict the soil erosion and sedimentation processes in a small-scale catchment, especially in Malaysia such as in the UPNM.
\end{abstract}

Keywords: Sediment transport, small-scale catchment, soil erosion, Abstrak
Model pengangkutan sedimen untuk lembangan sungai telah
dibangunkan pada berbagai skala temporal dan spasial. Walau
bagaimanapun, beberapa model telah dibangunakan untuk tadahan
berskala kecil dan masih disiasat oleh ramai penyelidik. Di dalam jurnal ini,
model yang berdasarkan proses telah dibangunkan untuk menilai
pengangkutan sedimen dalam tadahan berskala kecil. Integrasi model
hidrologi dan sedimen yang telah dibangunkan adalah untuk
mensimulasikan proses hakisan tanah dan pemendapan di kawasan
tadahan yang terletak di Universiti Pertahanan Nasional Malaysia (UPNM).
Hasil penemuan daripada simulasi sedimen dalam tempoh empat tahun
memberikan keputusan yang baik dengan purata Kecekapan Nash-
Sutcliffe (NSE) dan Pekali Korelasi (r) masing-masing adalah 0.60 dan 0.78 .
Selain itu, analisis sensitiviti mendedahkan bahawa sedimen di kawasan
tadahan UPNM dipengaruhi oleh parameter keterasingan tanah (Kf).
Secara keseluruhannya, output daripada model ini boleh diambil 
sebagai input untuk meramalkan proses hakisan tanah dan pemendapan dalam kawasan tadahan berskala kecil, terutamanya di Malaysia seperti di UPNM.

Kata kunci: Pengangkutan sedimen, tadahan berskala kecil, hakisan tanah, pemendapan sedimen, tadahan UPNM

(C) 2022 Penerbit UTM Press. All rights reserved

\subsection{INTRODUCTION}

Soil erosion and sediment transport are complicated natural processes that are significantly influenced by human activity, resulting in sedimentation problems, water pollution, and increased of flood occurrences. Sediment form the soil erosion or banks failure is transported into rivers, reservoirs, and ponds, resulting to excessive accumulation sediment, instability of banks and recurrent dredging operations. Effective river sediment management is becoming increasingly important from an economic, sociological, and environmental aspect. Using modeling techniques, transportation of sediment in river system may estimated quantitatively and consistenly [1]. Many models have been developed for a variety of uses and sizes, ranging from plot-based models to basinscale methods for erosion of soil and transportation of sediment.

Water Erosion Prediction Project (WEPP) [2] and European Soil Erosion Model (EUROSEM) [3] are the process-based sediment transport models which have been developed over the past four decades. However, the application of both sediment transport models remained questionable especially for the large basin scales (e.g drainage area $>100000 \mathrm{~km}^{2}$ ). Besides, some existing models were established for sediment transport in river, over land surface, or combination of land surface and in-river components might be useful for some situations.

The process-based model is built from basic equations expressing the water flow and bed morphology in a river system. Subsurface flow, surface runoff, evapotranspiration and ground flow are examples of physical processes that can be observed in the real world [4]. Models based on process provide a number of benefits over empirical and conceptual models, including the capacity to predict the temporal and geographical distributions of net soil loss on whole or single locations on hillslopes. Additionally, models based on process can calculate sediment simulation on a annual, monthly or daily basis. As a result, these models may be interpolated seasonally and used to a broad range of scenarios, some of which are hard to assess with field trials. Considering the complexity of the relation affecting on sediment dynamics, it is important to develop a comprehensive process-based model that can be used to anticipate the effects and consequences of natural processes along with human-effect on climate changes is important especially in major catchments.
The aim of this study is to enhance the understanding and knowledge on the selected existing sediment transport model for local catchment size. The model adopted in this study was developed based on combination of land surface and in-river components and the effectiveness was proven in two major Southeast Asia catchments: the Mekong and the Chao Phraya River Basin [5]. Land surface processes and in-river processes must both be included when predicting sediment formation and movement [1]. The goal of this work is to see if the established process-based model can be used to simulate sediment dynamics independently for hillslope sediment and sediment in river systems. To predict erosion of soil, deposition and transport in small catchments, model was built by combining a process erosion of soil and transport of sediment with spatially distributed model. This model has been calibrated and validate for Universiti Pertahanan Nasional Malaysia (UPNM) catchment.

\subsection{STUDY AREA}

The current study concentrated on the catchment of Universiti Pertahanan Nasional Malaysia (UPNM), which is situated in Wilayah Persekutuan Kuala Lumpur and encompasses an area of roughly $2.0 \mathrm{~km}^{2}$ (Figure 1). Forests make for around $33 \%$ of the catchment area. The rainy season which occur from May through October, with total annual rainfall averaging 80 to $90 \%$. While, dry season begins in November and continues till April. The average annual rainfall is 2000 $\mathrm{mm}$, with a maximum of $4000 \mathrm{~mm}$.

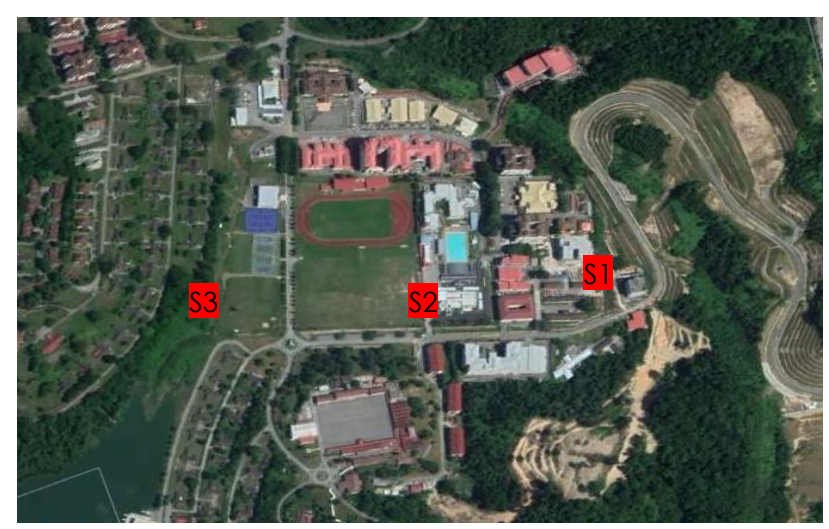

Figure 1 The UPNM catchment area (Source: Google Map, 2022) 
Acrisols were found the main soil type in this catchment that are tropical soils with a significant high accumulation clay and highly weathered and leached. The characteristics of soil have low fertility and sensitivity to soil erosion especially for agricultural practices. The areas of the catchment covered a combination of deciduous and evergreen tree. In addition, there are some undeveloped forest area in this catchment. The outputs (Q, SSC and SSL) at the three selected locations (S1, S2, and S3) were investigated (Figure 1).

\subsection{METHODOLOGY}

A process-based distributed hydrological model (DHM) were used as a model and integrate with major processes such as erosion of soil, transport and deposition of sediment (Figure 2). Sediment model was simulated by considering hill slope sediment and sediment in a river system separately. To provide a functional linkage for the adopted distribution model of hydrological, the sediment model was written using FORTRAN. The hydrological model was updated to include runoff and river routing. The sediment dynamics model was integrated the hydrologic process and soil erosion-sediment transport process in order to estimate daily data of soil erosion and deposition in the studied catchment. In general, the modeled aimed on suspended sediment load (SSL) because suspended sediment (SS) accounts as the majority of transportable sediment in most of global river [6] and it is commonly assumed that the suspended load comprises for roughly $90 \%$ of total load globally [7].

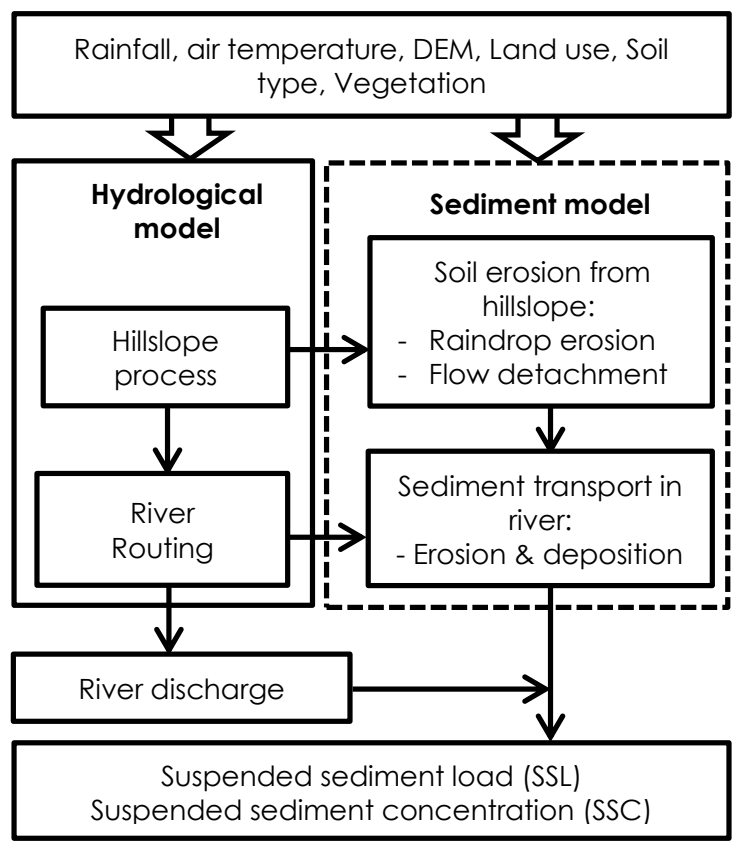

Figure 2 The distributed model structure

\subsection{Hydrological Model}

The geomorphology-based hydrological model (GBHM) created from the Yang et al. [8] was used in this study as the distributed hydrological model. It uses two modules which are hillslope and river routing to solves the continuity, momentum and energy equations.

The studied catchment area is subdivided to grids in the GBHM, and digital elevation model (DEM) was utilised for calculate the accumulation of flow river network and direction pattern. The intervals for water flow were determined by intervals from of the subbasin's outflow. The lateral flow into the river can be predicted by aggregated the runoff in each grid with a hillslope element. This indicates that all flow intervals on the hillside will flow in the river only. The GBHM was able to achieve a quick computation of flow including in larger basin due to flow hillslopeinterval mechanism. The hillslope element can be thought as an inclined plane in shape of a rectangular with a specific width and length. The angle of inclination is determined with the steepness of surface slope.

Each grid was formed into four levels in the hillslope model. Soil surface was cover with vegetation to prevent decisive rainfall onto the land. Canopy coverage and index of leaf area were used to compute the canopy interception deficit. The evapotranspiration module, which could also be employed with pan observation, reproduced the water volume evaporation from soil surface and transpired from a canopy. For the storage water by canopy, inside root and storage from soil surface, Priestley-Taylor's approach was used in the module. A one-dimensional was utilised for infiltration capacity of soil and water contents of soil inside plants zone to explain the unsaturated zone water flow. Basic Darcy's Law and mass balance equations is used to characterise the saturated of water and exchange flow with river. The saturation and infiltration excess discharged in a river system were determined by surface water flow modeling module.

The Pfafstetter numbering system is used in river routing to trace an efficiently of water flowing from upstream until downstream. Moreover, kinematic wave equations of one-dimensional are used to calculate water routing into river along river system. Further details explanation can be referred as in Yang et al. [8].

\subsection{Sediment Model}

\subsubsection{Soil Detachment}

The amount of soil detachment induced by raindrop was calculated using the equation as follow [9]:

$$
D_{R}=\left(1-C_{g}\right) k E e^{-z h}
$$

where $D_{R}$ is soil detachment by raindrop impacts (gm$\left.{ }^{2} \mathrm{~h}^{-1}\right), k$ is detachability soil index $\left(\mathrm{g} \mathrm{J}^{-1}\right), E$ is net kinetic 
energy by rainfall $\left(\mathrm{Jm}^{-2} \mathrm{~h}^{-1}\right), e^{-z h}$ is the coefficient of water ponding in which $z$ depends with soil texture (0.9-3.1) and $\mathrm{h}$ is a layer surface water depth $(\mathrm{mm})$. The ratio of soil surface shows in each grid is denoted by $C_{g}$. Raindrop impacts were divided into two categories: direct rainfall and leaf drip. The total kinetic energy $(E)$ can be expressed by the following equation:

$$
E=\left(1-C_{g}\right) E_{D} H_{D T}+C_{C} E_{L} H_{L D}
$$

where $\mathrm{C}_{c}$ is the canopy cover in each grid and calculated on a scale of 0.0 to 1.0 using land use data (0 represents bare land and 1.0 represents a densely forested area). HDT denotes the direct raindrops depth, which intensity of rain $\left(\mathrm{mmh}^{-1}\right)$ was utilised, and $E_{D}$ is energy of rainfall droplets $\left(\mathrm{Jm}^{-2} \mathrm{~mm}^{-1}\right)$. $H_{L D}$ is the net rain depth $\left(\mathrm{mmh}^{-1}\right)$ from leaf drip, which calculated by subtracting water interception loss from the rain intensity depth. $E_{L}$ is kinetic energy of leaf drip $\left(\mathrm{Jm}^{-2} \mathrm{~mm}^{-1}\right)$.

The Eq. (3) describes the kinetic energy of direct rainfall $E_{D}$ where I denote the intensity of rain $\left(\mathrm{mmh}^{-1}\right)$ [10].

$$
E_{D}=8.95+8.44 \log (I)
$$

As suggested by Brandt [11], EL represent the kinetic energy related to drip from leaf that can be determined using Eq. (4). The PH is canopy height as in unit meter. Similar to Kabir et al. [12], the $\mathrm{PH}$ adopted in this study was $1 \mathrm{~m}$.

$$
E_{L}=\left(15.8(P H)^{0.5}\right)-5.87
$$

The equations obtained from Habib-ur-Rehman and Akhtar [13] was utilised in this study and can be expressed as in Eqs. (5) and (6). These equations represent the soil detachment due to water flowing overland (6) when hydraulic shear stress is larger than critical hydraulic shear stress.

$$
\begin{aligned}
& D_{F}=K_{f}\left(\tau / \tau_{C}-1\right) \text { for } \tau>\tau_{C} \\
& D_{F}=0 \text { for } \tau<\tau_{C}
\end{aligned}
$$

wherein $D_{F}$ is overland flow detachment $\left(\mathrm{kgm}^{-2} \mathrm{~s}^{-1}\right), K_{f}$ is an overland flow detachability coefficient $\left(\mathrm{kgm}^{-2} \mathrm{~s}^{-1}\right)$, as for soil particle motion, $\tau_{c}$ is critical shear stress ( $\mathrm{Nm}^{-}$ ${ }^{2}$ ) as determined by the Shield's curve as well as a $\tau$ is the hydraulic shear stress $\left(\mathrm{Nm}^{-2}\right)$ that can be determined as in Eq. (7).

$$
\tau=\gamma h S
$$

where $h$ is depth on overland $(m)$ and $\gamma$ represent the specific weight for water $\left(\mathrm{Nm}^{-3}\right)$. The flow depth on overland was same as the water depth from surface in this study. The ground surface slope is denoted by $S$. $K_{f}$ was calibrated in Eq. (5), and values of critical shear stress was calculated using an equation below.

$$
\tau_{c}=N_{\text {sheilds }}\left(\gamma_{s}-\gamma\right) D_{s}
$$

where $N_{\text {sheilds }}$ is the shield parameter obtained from Shield's curve, $\gamma_{s}$ represent specific weight for sediment $\left(\mathrm{Nm}^{-3}\right)$, while $D_{s}$ represent the sediment particle size in unit $\mu \mathrm{m}$.

\subsubsection{Erosion and Deposition of Sediment}

In most cases, sediment erosion and deposition in rivers are considering to occur at the same time. Morgan et al. [14] highlighted that the Eq. (9) can be used to express the overland flow detachment or deposition.

$$
D F_{\text {river }}=\beta s w \vee s\left(T C-C_{S}\right)
$$

where DFriver is the flow of sediment detachment or deposition $\left(\mathrm{m}^{3} \mathrm{~s}^{-1} \mathrm{~m}^{-1}\right), C_{s}$ is sediment concentration in each flow intervals $\left(\mathrm{kgm}^{-3}\right)$. Furthermore, TC is transport capacity concentration $\left(\mathrm{kgm}^{-3}\right)$. Meanwhile, w represents the river flow width $(\mathrm{m})$ in every subbasin based on initial parameter for model, $v_{s}$ is sediment settling velocity $\left(\mathrm{m}^{-1}\right)$ which estimated from Stokes's Law. $\beta$ s represent a correction factor for computation of cohesion soil erosion as demonstrated in Eq. (10) mentioned by Kabir et al. [12].

$$
\beta s=0.79 e^{-0.85 J}
$$

in which $J$ is a cohesiveness of the soil ( $\mathrm{kPa}$ ). In order to calculate the transport capacity concentration, TC, different approaches have been proposed due to a basic structure and provided by model parameter data. The Eq. (11) was utilised to calculate SSL without taking into account bed loads, as presented by Govers [15].

$$
T C=c(\omega-\omega c r)^{\eta}
$$

where $\omega_{c r}$ is critical unit stream power $\left(\mathrm{cm} \mathrm{s}^{-1}\right), \omega$ is unit stream power $\left(\mathrm{cm} \mathrm{s}^{-1}\right)$ and assumed to be $10 \mathrm{Vs}$, as $V$ represent average velocity of flow $\left(\mathrm{cms}^{-1}\right)$, as s denote percentage of slope. Throughout for these case study, a $2.67 \mathrm{gcm}^{-3}$ is employed for soil density as conversions. While $c$ and $\eta$ are coefficients based from estimated median size of soil particle ( $d_{50}$ in $\left.\mu \mathrm{m}\right)$.

$$
\begin{gathered}
c=\left[\left(d_{50}+5\right) / 0.32\right]^{-0.6} \\
\eta=\left[\left(d_{50}+50\right) / 300\right]^{0.25}
\end{gathered}
$$

As for sediments transported in every grid cell were estimated from correlating it with water discharge, following by concept of mass and momentum conservative similar to the flow simulation in the distributed hydrological model. In simulation of sediment transport within land and in the river, the kinematic wave and finite difference approach was utilised. The water flow and soil movement on the land grids was gathered at each flow distance using weighting scheme calculated from distance of the 
main stream. The flow accumulated then was released as laterally flow into the main river. The river node's water discharge (Q) was calculated using a single kinematic wave approximation. The river routing model was also used to compute the suspended sediment concentration movement (Cs) by utilizing the kinematic wave equation and the supplied $Q$.

\subsection{Model Set-up, Calibration and Validation}

The meteorological, topographical, land cover and soil properties were among the input data for the model. The drainage maps and slope in this study were obtained from the topographical survey. ERDAS Imagine was used to construct the map for soil, land cover and DEM. While, the UPNM weather station provided the data of air temperature and daily precipitation.

The collecting field data provided monthly data of SSC and flow discharge as in this study. At targeting stations in the UPNM catchment, the field record tabulated measurements of flow discharge and SSC. The SSC and flow discharge data from the target stations were selected and utilised for simulation of SSL in this study. The selected stations were based primarily on both proximities and reliabilities of flow discharge and sediment data. The SSC was collected monthly basis and measured at a depth of $0.3 \mathrm{~m}$ from the water surface at the center of the river.

The model was simulated to predict $Q$, SSC and SSL from year 2016 to 2019. There were three selected stations along the river which used for calibration and validation process (Figure 2). The monthly discharge and sediment data from 2016 until 2017 were utilised for calibration of discharge simulation. While for validation purposes, the monthly data from the years of 2018 to 2019 were used. Generally, the sediment diameter in this catchment was in range of $<62 \mu \mathrm{m}$ to $<2 \mu \mathrm{m}$. Hence, the sediment diameter of $50 \mu \mathrm{m}$ was chosen as the sediment particle size $\left(d_{50}\right)$ in this study.

Table 1 Model parameters calibrated for UPNM catchment

\begin{tabular}{lc}
\hline Hydrological model & UPNM \\
Saturated hydraulic conductivity of & $4.6-30.4$ \\
surface soil, ksatl $\left(\mathrm{mm} \mathrm{hr}^{-1}\right)$ & \\
Residual soil moisture, wrsd $\left(\mathrm{mm} \mathrm{hr}^{-1}\right)$ & $0.16-0.19$ \\
\hline Sediment model & \\
Raindrop, $k\left(\mathrm{~g} \mathrm{~J}^{-1}\right)$ & $7.0-100.0$ \\
Overland flow, $K_{f}\left(\mathrm{mg} \mathrm{m}^{-2} \mathrm{~s}^{-1}\right)$ & $1.0-10.0$ \\
Soil cohesion, $J(\mathrm{kPa})$ & $3.0-5.0$ \\
\hline
\end{tabular}

The five parameters are listed in Table 1 were calibrated with SSL and flow discharge measured at three selected stations after being initialised with empirical values. The SCE [16] were used for calibrating all of the parameters. Observation at S1 was used to calibrate parameters that mainly represent the upper catchment. Meanwhile, observation at $\mathrm{S} 2$ has been used to calibrate parameters which only represent the middle catchment, and S3 was being used to calibrate parameters that only reflect the lower catchment. The NSE [17] and coefficients of correlation (r) was applied for evaluate fits with simulated and observed outputs ( $Q$ and SSL) on monthly intervals between 2017 till 2019.

\subsection{RESULTS AND DISCUSSION}

\subsection{Model Performance}

The UPNM catchment's flow discharge were successfully simulated at certain selected locations (Table 2). Figure 3 shows the simulated hydrographs from year of 2016 to 2019. The NSE values for flow discharge at S1, S2, and S3 were exceeded 0.7 for calibrate and validate, respectively. The averaged correlation ( $r$ ) for discharge of simulation and observation were also in good agreement where $r>$ 0.8. Overall, the simulation results show as the GBHM adequately captured the seasonal and spatial pattern distributions of all hydrological process in UPNM catchment, despite a fact that the simulated discharge had slightly higher peaks.

Table 2 Model performance indicators for monthly flow discharge, SSL, and SSC in UPNM from 2016 to 2019

\begin{tabular}{|c|c|c|c|c|}
\hline \multirow[t]{3}{*}{ Stations } & \multicolumn{4}{|c|}{ Performance indicators } \\
\hline & \multicolumn{2}{|c|}{$\begin{array}{l}\text { Calibration } \\
2016-2017\end{array}$} & \multicolumn{2}{|c|}{$\begin{array}{c}\text { Validation } \\
2018-2019\end{array}$} \\
\hline & NSE & $r$ & NSE & $r$ \\
\hline \multicolumn{5}{|c|}{ Flow discharge } \\
\hline S1 & 0.71 & 0.81 & 0.71 & 0.86 \\
\hline S2 & 0.77 & 0.87 & 0.74 & 0.86 \\
\hline S3 & 0.84 & 0.87 & 0.85 & 0.86 \\
\hline \multicolumn{5}{|c|}{ Suspended sediment load (SSL) } \\
\hline S1 & 0.62 & 0.85 & 0.51 & 0.65 \\
\hline S2 & 0.62 & 0.86 & 0.62 & 0.83 \\
\hline s3 & 0.64 & 0.80 & 0.64 & 0.87 \\
\hline \multicolumn{5}{|c|}{ Suspended sediment concentration (SSC) } \\
\hline S1 & 0.08 & 0.58 & -4.33 & 0.31 \\
\hline S2 & -0.07 & 0.43 & -0.25 & 0.73 \\
\hline S3 & -0.07 & 0.66 & -1.02 & 0.78 \\
\hline
\end{tabular}

Despite diverse physical characteristics such like topography (e.g., rill, interill, and gully) and soil structure in the UPNM catchment, wider ranges for $k$ and $K_{f}$ were determine, while the range of $J$ is slightly narrowed for calibrated the sediment model. The range $k$ used in UPNM catchment is between 7.0 and $100 \mathrm{kgJ}^{-1}$ which is wider compared with other study probably because of the soil structure and content. UPNM catchment is mostly covered by clay soils, which is a possible reason why SSL is not sensitive to $k$ and $k$ is not important for sediment yield in this catchment study.

Figure 4 displays the comparison of simulated and observed monthly SSL at three selected locations from 
the year of 2016 to 2019 . As tabulated in Table 2, the simulated SSL are in line with observations. During calibration (2016-2017) and validation (2018-2019) periods, the value of NSE exceeded of 0.6 for all locations, with the exception of validation period at the upper location (S1) where NSE = 0.51. At upper (S1) location, the model simulation underestimated the situation (Figure 4). Nonetheless, for all three locations, the linear coefficient of correlation $(r)$ within simulated and recorded SSL had been as in ranges between 0.80-0.86. The SSL were generally adequately simulated in all three locations (Figure 4).

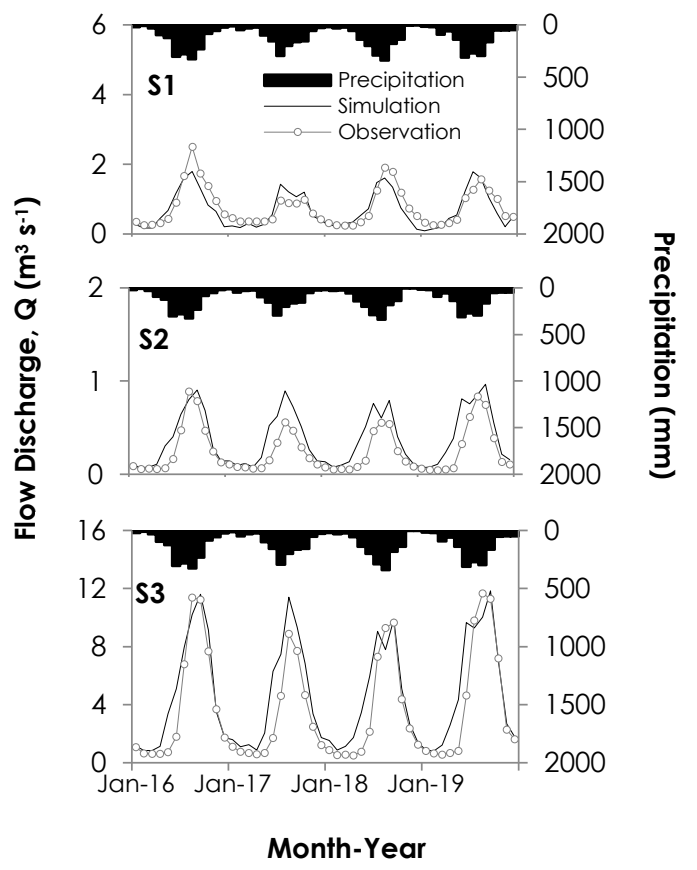

Figure 3 Monthly average flow discharge at targeted locations from 2016 to 2019 at UPNM catchment
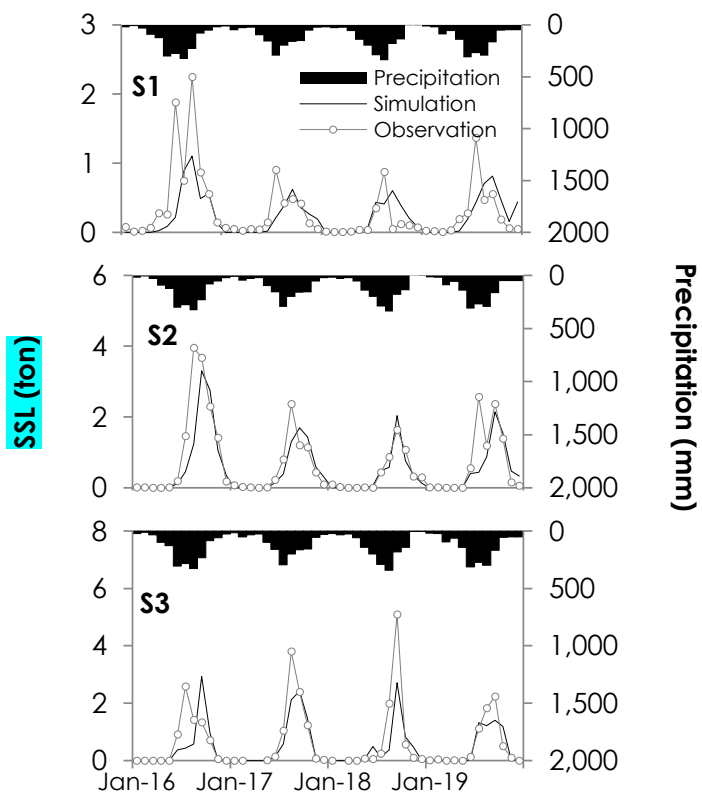

Figure 4 Monthly suspendifi-sediment load (SSL) at targeted locations in the UPNM catchment for 2016-2019
The results of simulation describe the seasonal pattern of SSL in UPNM catchment and higher SSL is expected during the rainy season (May to Oct) as also describe by Sok et al. [18]. The simulated results reveal that, for the entire period of 2016-2019, the average annual SSL were the highest $\left(8.9 \mathrm{t} \mathrm{yr}^{-1}\right)$ at middle region, whereas the upper and lower regions showed an average annual SSL, 3.4 and $5.6 \dagger^{y^{-1}}$, respectively. Binh et al. [19] reported that the annual SSL is high in the middle region before increasing further downstream. The simulated result also revealed the high SSL in the middle region compared with other regions probably due to large tributary drainage area. The annual SSL at lower region of UPNM catchment tends to increase according as the increasing catchment area.

Figure 5 shows the simulation of SSC in monthly at selected measured stations from 2016 to 2019. The coefficient of correlation $(r)$ is greater than 0.5 within observed and modelled SSC in monthly at all selected stations (Table 2). The RMSE within measured and modelled SSC are $0.31 \mathrm{~kg} \mathrm{~m}^{-3}$ at S1, $0.25 \mathrm{~kg} \mathrm{~m}^{-3}$ at S2, and $0.14 \mathrm{~kg} \mathrm{~m}^{-3}$ at S3. The outcomes indicate that the SSC is decreasing in all three stations from upper to down area (Figure 5). The S1 station has the highest average monthly SSC with an estimated is $0.33 \mathrm{~kg} \mathrm{~m}^{-3}$. Meanwhile, S3 shows average SSC were the smallest with a calculated value is $0.13 \mathrm{~kg} \mathrm{~m}^{-3}$. Sediment accumulation in lower region caused the low value at S3. This trend was caused by a reduction of water velocity in main stream, which increases deposition of sediment and lowers SSC.

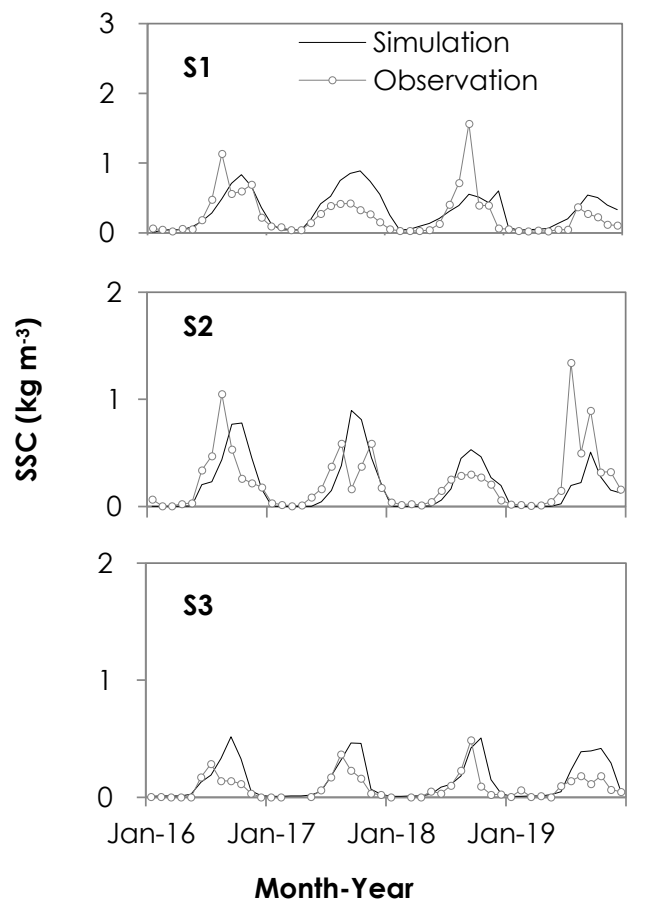

Figure 5 Monthly suspended sediment concentration (SSC) at targeted stations in UPNM catchment for 2016-2019 
The concentration of SSC was likewise increased in wet season rather than dry season according to the model results (Figure 5). This is caused to extensive soil erosion, which is primarily caused by excessive rainfall during the wet season. The upper station's high simulated SSC in July was in line with observed SSC, which reported the initial concentrations is high during wet season as in mid-July. Furthermore, recorded SSC continues to decrease after mid-August and continued to decrease from early September. The pattern of simulated SSC demonstrated a decrease within August to September, which matched this tendency.

\subsection{Sensitivity of SSL to sediment-related parameters}

SSL in the UPNM catchment was subjected to a sensitivity analysis. To begin, all of the parameters were calibrated to the following values: $k=7 \mathrm{gJ}^{-1}, \mathrm{~J}=3 \mathrm{kPa}$ and as for $K_{f}=1 \mathrm{mg} \mathrm{m}^{-2} \mathrm{~s}^{-1}$. Then, SSL were simulated at $\$ 2$ among every parameter for 2018.

The simulated findings showed that peak SSL rises less during September since the initial value of $k$ is reduces to $50 \%$ (Figure 6a). Furthermore, the peak SSL continued to rise and showed smaller variations with successive decreases by a $25 \%$ from the initial value. As a result, SSL is becoming susceptible to $k$ in UPNM catchment. Despite the fact that studies of soil strength for sands, loams, and clays [20] demonstrate that $k$ declines while strength of soil increases. Because of SSL modest reaction to changing $k$, clay soil strength and content appear to be irrelevant. The sensitivity analysis found that soil detachment from raindrops plays a minor role in SSL formation in the UPNM catchment.

In terms of $K_{f}$, due to increased detachability of soil by sheet flow shows that SSL peaks reduced by $40 \%$ when multiplied by a factor of 100 in year 2018 (Figure 6b). With decreasing $K_{f}$ also shows the simulated SSL also reduced substantially (using factors 0.1 and 0.01 ). The simulation result of SSL shows the opposing patterns as Suif et al. [1], which observed that the peaks SSL increased with increasing $K_{f}$ values from August to October with value ranging from 0.4 till 0.6 $\mathrm{mg} \mathrm{m}^{-2} \mathrm{~s}^{-1}$. Thus, these implies the separated of soil by sheet flow become an essential factor for transported SSL in UPNM catchment channel. There are no definite data on the sensitivity range of $K_{f}$ in the literature [21; 22].

The peak SSL of September increased by 150 percent with multiplied by 1.25 for soil cohesiveness $(\mathrm{J})$ (Figure $6 \mathrm{c}$ ), according to the data. On the other hand, the percentage of SSL peak is reduced from 70 to 80 $\%$ when soil cohesiveness multiplied is reduced from 0.75 to 0.5 approximately. The changes of SSL become further susceptible to soil cohesion either $k$ or $K_{f}$ because soil cohesion shows soil detachability inside channel. Soil cohesion limits sediment detachment in equations of total soil detachment for channels (Eqs. 9 and 10). There is a link between soil cohesiveness and erodibility, although no specific relation occurs even for a specific soil size [15].
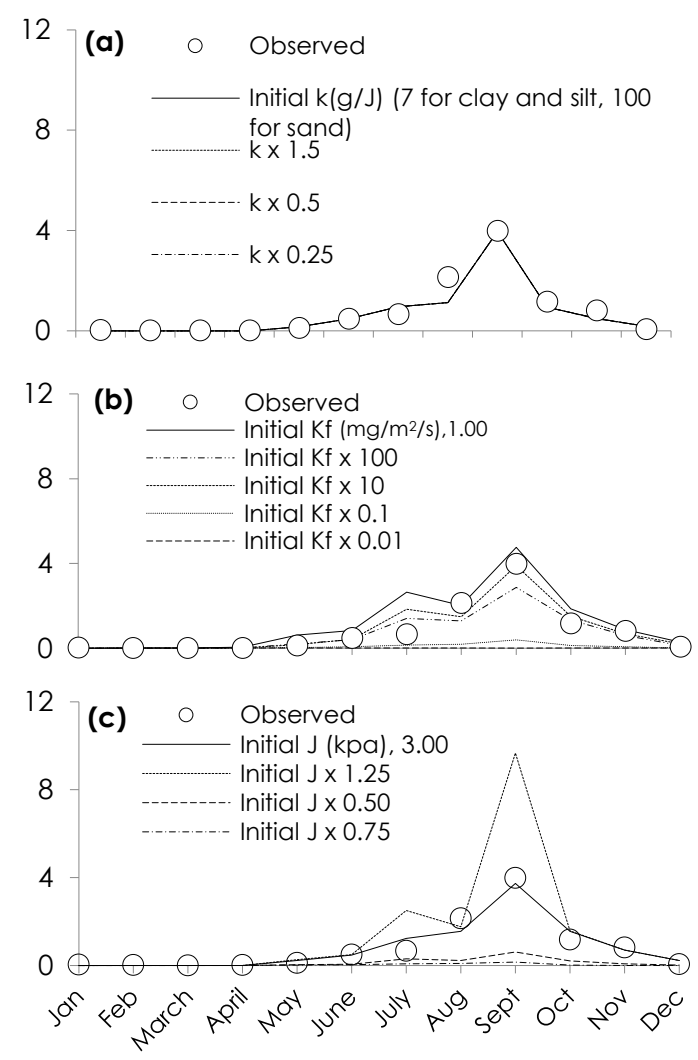

Figure 6 Sensitivity of suspended sediment load (SSL) at S2 to (a) detachability from rain drop (k), (b) detachability from sheet flow $\left(K_{\mathrm{f}}\right),(\mathbf{c})$ soil cohesion $(J)$. Difference among lines in Figure (a) is invisible due to the minor response of SSL to $k$

SSL's output is strongly influenced by the three input factors which represent soil erodibility. In general, the most sensitive parameter in the UPNM catchment is soil cohesiveness (J). The SSL change in the UPNM catchment was influenced by soil detachability over land $\left(K_{f}\right)$.

\subsection{CONCLUSION}

A sediment transport model was developed by integration with a distributed hydrological model in this work to target a small catchment scale. The developed model allows us to simulate dynamics of rainfall-runoff and transport of sediment over hillslope and within a river network. The dynamics of sediment over hillslope was adequately modeled over its application to the UPNM catchment. It can identify areas with significant dynamics of sediment on a fine grid scale because is a grid-based model.

Furthermore, the current model developments measured soil detachability $\left(k, K_{f}\right)$ and cohesiveness (J) within the channel, revealing the UPNM catchment's significant sensitivity to soil detachability $\left(k, K_{f}\right)$. Due to the insufficient information on these case study, the current model presumed only specific SS size rather than a variation range size of SS. As a result, 
the sediment model's application in this case study may have been limited due to poor modeling of SS size distribution. As a result, integrating multi-size sediment particles into the model may improves model performance even more.

Nonetheless, the model's results at the basin level may be valuable to decision-makers, developers and stakeholders in plan and implement the basin management methods over sediment may also be combined alongside water resources management. Furthermore, the developed model may be utilized for estimation of sediment dynamic effects from anthropogenic activities in small catchment over various scenarios.

\section{Acknowledgement}

This research for UPNM catchment is fully supported through Fundamental Research Grant Scheme (RACER/1/2019/TK01/UPNM/1). The authors fully acknowledged Ministry of Higher Education (MOHE) and Universiti Pertahanan Nasional Malaysia for the approved fund which makes this important research viable and effective.

\section{References}

[1] Suif, Z., Fleifle, A., Yoshimura, C. and Saavedra, O. 2015 Spatio-temporal Patterns of Soil Erosion and Suspended Sediment Dynamics in the Mekong River Basin. Science of Total Environment. 568: 933-945.

[2] Nearing, M. A., Foster, G.R., Lane, L. J. and Finckner, S. C. 1989. A Process-based Soil Erosion Model for USDA-Water Erosion Prediction Project Technology. Transactions of the American Society of Agricultural Engineers. 32: 1587-1593.

[3] Morgan, R. P. C., Quinton, J. N. and Rickson, R. J. 1993. EUROSEM Version 3.1 a User Guide. Silsoe College, Cranfield University, Silsoe, Bedford, UK, 83.

[4] Pfannerstill, M., Guse, B., Reusser, D. and Fohrer, N. 2015. Process Verification of a Hydrological Model using a Temporal Parameter Sensitivity Analysis. Hydrol. Earth Syst. Sci. 19: 4365-4376. Doi:10.5194/hess-19-4365-2015.

[5] Suif, Z., Yoshimura, C., Ahmad, N., and Hul, S. 2018. Distributed Model of Hydrological and Sediment Transport Process in Mekong River Basin. International Journal of GEOMATE. 14(42): 134-139.

[6] Li, L., Ni, J., Chang, F., Yue, Y., Frolova, N., F., Magritsky, D., Borthwick, A. G. L., Ciais, P., Wang, Y., Zheng, C., Walling, D. E. 2020. Global Trends in Water and Sediment Fluxes of the World's Large Rivers. Science Bulletin. 65(1): 62-69.

[7] Best, J. 2018. Anthropogenic Stresses on the World's Big Rivers. Nat. Geosci. 12(1): 7-21.
[8] Yang, D., Herath, S., Oki, T., and Musiake, K. 2001. Application of Distributed Hydrological Model in the Asian Monsoon Tropic Region with a Perspective of Coupling with Atmospheric Models. J. Meteorol. Soc. Jpn. 79: 373385.

[9] Torri, D., Sfalanga, M., and Delsette, M. 1987. Splash Detachment-runoff Depth and Soil Cohesion. Catena. 14: 149-155.

[10] Brandt, C. J. 1989. The Size Distribution of Throughfall Drops Under Vegetation Canopies. Catena. 16: 507-524.

[11] Brandt, C. J. 1990. Simulation of Size Distribution and Erosivity of Raindrops and Throughfall Drops. Earth Surf. Proc. Land. 15: 687-689.

[12] Kabir, M. A., Dutta, D., and Hironaka, S. 2011. Processbased Distributed Modeling Approach for Analysis of Sediment Dynamics in a River Basin. Hydrol. Earth Syst. Sci. 15: 1307-1321. DOI:10.5194/hess-15-1307-2011.

[13] Habib-ur-Rehman, M. and Naeem Akhtar, M. 2004. Development of Regional Scale Soil Erosion And Sediment Transport Model; Its Calibration and Validations. 69th Annual Session. Proceedings of Pakistan Engineering Congress, Lahore, Pakistan. April, 231-245.

[14] Morgan, R. P. C., Quinton, J. N., Smith, R. E., Govers, G., Poesen, W. A., Auerswald, K., Chisci, G., Torri, D., and Styczen, M. E. 1998. The European Soil Erosion Model (EUROSEM): A Dynamic Approach for Predicting Sediment Transport from Fields and Small Catchments. Earth Surf. Proc. Land. 23: 527-544.

[15] Govers, G. 1990. Empirical Relationships for the Transport Capacity of Overland Flow. Erosion, Transport and Deposition Processes. IAHS Publ. 189: 45-63.

[16] Duan, Q., Soorooshian, S., and Gupta, V. 1992. Effective and Efficient Global Optimization for Conceptual Rainfallrunoff Models. Water Resour. Res. 28: 1015-1031.

[17] Nash, J. E. and Sutcliffe, J. V. 1970. River Flow Forecasting through, Part I: A Conceptual Models Discussion of Principles. J. Hydrol. 10: 282-290.

[18] Sok, T., Oeurng, C., Kaing, V., Sauvage, S., Kondolf, G. M. and Pérez, J. M. S. 2021. Assessment of Suspended Sediment Load Variability in the Tonle Sap and Lower Mekong Rivers, Cambodia. Catena. 202: 105291. Doi: 10.1016/j.catena.2021.105291.

[19] Binh, D. V., Kantoush, S. and Sumi, T. 2020. Changes to Long-term Discharge and Sediment Loads in the Vietnamese Mekong Delta Caused by Upstream Dams. Geomorphology. 353: 107011. Doi: 10.1016/j.geomorph.2019.107011

[20] Suif, Z., Razak, M. A. A. A. and Ahmad, N. 2018. Predicting of Soil Erosion with Regarding to Rainfall Erosivity and Soil Erodibility. AIP Conference Proceedings. 1930: 020054. Doi: 10.1063/1.5022948.

[21] Suif, Z., Yoshimura, C., Saavedra, O., Ahmad, N. and Hul, S. 2017. Suspended Sediment Dynamics Changes in Mekong River Basin: Possible Impacts of Dams and Climate Change. International of GEOMATE. 12(34): 140-145.

[22] Swarnkar, S., Tripathi, S. and Sinha, R. 2021. Understanding Hydrogeomorphic and Climatic Controls on Soil Erosion and Sediment Dynamics in Large Himalayan basins. Science of The Total Environment. 795: 148972. Doi: 10.1016/j.scitotenv.2021.148972.f 